\title{
FIJI
}

\section{The evolution of media laws in Fiji and impacts on journalism and society}

\begin{abstract}
This article examines the cultural, political, ethnic and economic forces that have shaped the evolution of media legislation in Fiji and the evident impacts on journalism and society. The article argues that despite Fiji's British colonial heritage and its smooth transition to democracy after Independence in 1970, the spectre of stricter legislation has been a constant threat. This threat finally materialised in the post-2006 coup period, when media-related laws underwent a major overhaul, including the promulgation of the punitive Media Industry Development Decree 2010, which was later 'preserved' under the 2013 Constitution despite being labelled 'undemocratic'. The 2006 coup leader Voreqe Bainimarama, who was decisively voted back into power as Prime Minister in the 2014 General Election, justified the media reforms in the name of social stability and progress. This research uses document review to examine the genesis, nature and efficacy of Fiji's media-related laws, from the colonial to postcolonial periods, and beyond.
\end{abstract}

Keywords: democracy, elections, ethno-nationalism, Fiji, media law, military coups, military government

\section{SHAILENDRA SINGH}

University of the South Pacific, Fiji

- OR MOST of the colonial and post-colonial periods, Fiji’s media-related laws were ostensibly on a par with some of the world's leading democracies, including neighbours Australia and New Zealand (S. Singh, 2010). This situation changed following the country's fourth coup in December 2006, staged by military commander Commodore Voreqe Bainimarama, who ruled for eight years before he was elected Prime Minister in the September 2014 General Election. Shortly after the coup, Bainimarama's militarybacked government embarked on the most intense and sustained media crackdown in the country's history, claimed to be justified on the basis of improving journalistic professionalism, curbing inflammatory reporting, and ensuring social stability in a post-coup situation.

126 PACIFIC JOURNALISM REVIEW 21(1) 2015 
Initially, Government agents used crude, intimidatory methods, such as threats and occasional assaults on journalists, to exert control. Later, they resorted to more sophisticated strategies, such as media decrees and emergency laws. These included the 2009 Public Emergency Regulations (PER), which gave the authorities sweeping censorship powers, and the punitive Media Industry Development Decree 2010, which replaced self-regulation with government regulation, and criminalised what were once regarded as ethical breaches (Crimes Decree, 2009). Another law, the 2009 Crimes Decree, specifies maximum 10year jail sentences for inciting political and communal antagonism through any form of communication (Crimes Decree, 2009; Media Industry Development Decree ... 2010).

Based on document review method, this article looks at the genealogy and evolution of Fiji's media laws to understand how they arrived at their current point, and their impact on journalism. The article attempts to determine the efficacy of the major media-related legislation in terms of achieving its purported aims - facilitation of communal harmony and the enhancement of journalistic standards - as expressed by government (SayedKhaiyum, 2010; Bainimarama, 2012).

Based on empirical evidence, the article argues that the freedoms historically enjoyed by the Fiji media have always been fragile, even under democratic rule. In spite of constitutional guarantees, harsher legislation seemed inevitable, not only due to the autocratic mindset of successive governments (which has received a lot of attention), but also because certain British-inherited Fourth Estate traditions were at odds with Fiji's 'hybrid' democracy, based on a combination of Western and Indigenous systems of governance (see Boege et al., 2008; Robie, 2014).

In addition, various conventional media approaches and philosophies are in conflict with Indigenous Fijian norms of deference for traditional authority and avoidance of direct conflict (see Madraiwiwi, 2014). This cultural clash could explain the apparent public support for stronger media legislation detected in the 2011 Lowy Institute poll. The poll returned a strong approval rating for Bainimarama, which some disputed (Lowy Institute, 2011).

Yet another overlooked variable is the multi-ethnic nature of Fijian society and the ethnically-based political system. This often meant that political support was based along ethnic lines, rather than ideological lines, at least according to some viewpoints (Kant, 2013). The apparent public support for stronger media legislation (Lowy Institute, 2011) could be an indication of a low level of public tolerance for media opposition, said to be a feature of pluralistic societies (Fong, 2009).

A possible byproduct of these political, cultural and ethnic variables is an apparent measure of public support for stronger media legislation, as seen in the 2011 Lowy Poll (Lowy Institute, 2011). To contextualise, Fiji's media have been credited with exposing corruption and challenging military governments, but they are also said to lack cultural sensitivity, professionalism and educational standards (see Robie, 2001, 2013, 2014). The Fiji media, being paradoxically described as both a national security threat and champion 
POLITICAL JOURNALISM IN THE ASIA-PACIFIC

of democracy, reflects the country's complex socio-political setting (see Boege et al., 2013; Kant, 2012).

As this research will argue, governments have sensed, and capitalised on, the public's conflicting moods towards the media (see Lowy Institute, 2011) to propose, or in the case of the Bainimarama Administration, to impose stronger media legislation.

\section{Methodology}

This research uses various consultancy reports on the Fiji media sector, media decrees and other legislation, news reporting frameworks and training manuals, Fiji's four national constitutions (1970, 1990, 1997 and 2013), various speeches and presentations, and Government bills and legislation.

With regard to media law, much of the focus has been on the Bainimarama government and its punitive legislation. This is understandable: media freedom, as it is conventionally understood, had withstood three previous coups in Fiji in 1987 and 2000. The change in the media's status as a result of the 2006 coup was sudden, dramatic and profound.

To really understand how the legislation arrived at its current point, one needs to look at the situation in totality, incorporating the relevant variables-social, economic and political — over time and space. Subsequently, this analysis is guided by a constructivist paradigm, which analyses phenomena by connecting trends, processes and people over time and space, rather than focusing on individuals and events in isolation (see Houge, 2011; Conteh-Morgan, 2005; McLeod 2009). This approach dovetails with Frohardt and Temin's (2003) conflict reporting framework, which is based on studying the genealogy and nature of media legislation to understand the influences that shaped its evolution, before analysing its impacts. Consequent to the methodology, the presentation of results and analysis will be guided by the following three key variables:

1. The history of past legislation, which is normally an indicator of future trends in legislation.

2. The degree of media freedom established in the country's laws. This indicates the balance between legislation guaranteeing the media freedom to operate without excessive government interference and legislation covering privacy, libel, slander and hate speech to protect individuals.

3. The consistency, sincerity and fairness with which the legislation is applied. This is usually an indication of the independence and impartiality of the judicial system (see Frohardt \& Temin, 2003).

\section{Results and analysis}

History of past legislation

Regarding the first indicator, 'history of past legislation', complaints about the media's ostensible provocation of ethnic tensions have persisted since the establishment of the press in Fiji, in the form of the country's first newspaper, The Fiji Times, in 1869. In the 
19th and most of the 20th centuries, it was alleged many times that The Fiji Times supported a 'White Fiji' campaign by attempting to drive a wedge between indigenous Fijians and Indian labourers, the latter brought by the British to develop the sugar industry (Gillion, 1977; Gaunder, 2008; Heartfield, 2002). One letter published in March 1922 described Indians as 'evil smelling' and 'treacherous' (Gillion, 1977, p. 81). It prompted then acting Governor Fell to consider legislation to prevent newspapers "promoting racial discord', but there was no such legal precedent in the British Empire to follow through (Gillion, 1977, p. 82).

In the 1960s, the then editor of The Fiji Times, Len Usher, prompted calls for media control when he accused Indigenous Fijian leader and founding Prime Minister Ratu Sir Kamisese Mara of 'lavishing praise' on the Indo-Fijian Opposition. Ratu Mara, in turn, accused the paper of opposing his efforts to promote ethnic co-operation. Even Opposition MP K. C. Ramrakha, warned: 'We must strangle this newspaper before it strangles us, and I mean it' (see Gaunder, 2008, p. 257).

The question of stronger legislation receded in the face of two key developments - the euphoria over Fiji's independence in 1970 and the arrival of the country's second newspaper, the Fiji Sun, in 1974. The Sun was jointly owned by the Hong Kong-based Sally Aw Sian publishing empire and New Zealand publisher Philip Harkness (see Gaunder, 2008; Robie, 2001, p. 151).

The buoyant post-colonial mood, coupled with the harsh realities of competition conceivably forced The Fiji Times to drop its rhetoric. As the political and economic power of the European establishment dwindled, the paper noticeably re-invented itself from a publication catering for the elites to one that moved closer to the mainstream. This metamorphosis fitted into a global paradigm shift in the early 19th century, when market imperatives in the US and other countries forced newspapers to abandon partisanship and embrace the middle ground (Fengler \& Ruß-Mohl, 2008, p. 676).

In Fiji, the liberties enshrined in the 1970 Constitution were a catalyst for further changes. Chapter two, section 3 of the constitution guaranteed the freedom of 'conscience, expression, assembly and association', constrained by the respect for the rights and freedoms of others (Fiji Independence Order 1970 and Constitution of Fiji, 1970, pp. 18-19).

However, virtually all Fiji governments since 1970, whether elected or unelected, have threatened to introduce tougher media laws, usually in response to embarrassing media disclosures, or alleged lack of media professionalism (see Robie, 2009; Sutherland, 1992).

The 1987 coup, first brush with censorship and the heady 1990s

As the country's post-Independence honeymoon period cooled off, the political climate heated up, culminating in the 1987 nationalist coups against perceived Indo-Fijian political dominance. This saw the media experience their first real brush with censorship, short-lived as it was (Pareti, 2009). The Fiji Sun reportedly closed rather than publish under self-censorship restrictions. A new publication, the Fiji Daily Post, began operations in October 1987, eventually becoming the country's third daily (Robie, 2001). 
POLITICAL JOURNALISM IN THE ASIA-PACIFIC

While the military imposed restrictions in the post-1987 coup period in the name of preserving social order, it used the Indigenous Fijian vernacular newspaper, Nai Lalakai, and the Fijian programme on the state broadcaster to promote the coup ideology, further sowing suspicion between the two major ethnicities (Ewins, 1998). A byproduct of the 1987 coups was the new 1990 Constitution, implemented in the name of Indigenous Fijian political supremacy. In reality, the constitution entrenched the power of Indigenous chiefs and other elites, besides propelling 1987 coup leader Sitiveni Rabuka, to the prime ministership (see Ewins, 1998). Based partly on traditionalism, certain sections of the constitution were in conflict with the British heritage of the Fiji press.

Section 13(2) granted special protections to the reputation, dignity and esteem of indigenous institutions and values, putting them virtually above criticism. Such institutions included the Great Council of Chiefs, although some argue that the chiefs' body is a British invention to implement rule by proxy (Constitution of the Sovereign Democratic Republic of Fiji, 1990; also see Ewins, 1998). Among other things, the 1990 constitution was a possible outcome of the tensions between Indigenous cultural norms of respect for traditional authority on the one hand (Madraiwiwi, 2014) and the egalitarianism that news media supposedly embrace as their guiding principle (see Christians et al., 2009).

Constitutionally and politically, the Rabuka government embraced traditionalism. Economically, the government adopted free-market reforms as part of the globalisation agenda (Firth, 2000). This led to the further opening of the economy in the 1980s and 1990 s, marking one of the most robust periods in the media sector's evolution. Aside from acting as a trigger for re-investment in existing media companies, deregulation spawned a plethora of new companies, both in print and commercial broadcast, ending government's monopoly of the airwaves (Bhagwan-Rolls, 2007). One commentator described the scene as 'saturated to the point of overflowing', with three dailies, eight commercial radio stations, three monthly business magazines and one commercial TV station, owned by the state and various private interests (Digitaki, 2000).

The 1990s also marked a strong shift towards the internet. Associated Media Limited, the parent company of the now non-operational news and business magazine, The Review, was a pioneer in this field, as was Communications Fiji Limited (Digitaki, 2000). These developments were marked by a bigger, brasher and bolder journalist corps making new strides into previously uncharted territory, most notably investigative journalism. This trend drove government-media tensions to new highs (see Digitaki, 2000; Rabuka and the reporter, 1994).

Monthly magazine The Review, published by award-winning Fiji journalist Yashwant Gaundar, exposed the National Bank of Fiji collapse, implicating prominent politicians, businesses and citizens in the F\$372 million (NZ\$242million) scam (S. Reddy, 2010; also see Grynberg, Munro \& White, 2002). The Review also broke an unwritten taboo by exposing Fiji's first political sex scandal between Prime Minister Rabuka and a female

130 PACIFIC JOURNALISM REVIEW 21(1) 2015 
journalist. Certain Rabuka government ministers threatened stronger media legislation, only to back down since the country was democratising, and the government craved international legitimacy (Rabuka and the reporter, 1994).

In order to deal with what it regarded as increasingly belligerent media, the Rabuka government opted for an internationally more palatable plan. In 1996 it commissioned the Thomson Foundation of Britain to carry out a study on 'Future Media Legislation and Regulation for the Republic of the Fiji Islands' (Robie, 2009).

The ensuing report, implemented in 1998, recommended an independent, nongovernmental regulating body, paving the way for the establishment of British-style self-regulation via a media industry-funded Fiji Media Council. Self-regulation was compatible with Fiji's democratic reforms, including the newly-adopted 1997 Constitution, which was deemed fairer than the racially-weighted 1990 Constitution. The Constitution's preamble recognised the 'human rights and fundamental freedoms' of all groups (Constitution of the Republic of the Fiji Islands, 1997, p. 9). The media drew their authority from section 30 , which stated that 'every person has the right to freedom of speech and expression, including: (a) freedom to seek, receive and impart information and ideas; and (b) freedom of the press and other media' (p. 21).

Constitutional guarantees coupled with market deregulation and media self-regulation stimulated further competition in the media sector. This led to a somewhat jingoistic media environment, with a proliferation of what might be considered as both good and bad journalism. If investigative journalism reached new heights, then media tabloidisation reached new lows. Market pressures saw the financially-ailing Fiji Daily Post resort to headline stories of alleged ghost sightings in Parliament House and a woman giving birth to snakes (Usman, 2012). This phase did not last. Still, it was fodder for a government trying to justify the introduction of stronger media laws.

As government-media tensions increased, there were renewed calls from conservative politicians for strict, Singaporean-style media legislation (Committee to Protect Journalists, 1998). In Singapore, 'uninhibited' reporting was blamed for ethnic riots in the 1950s and 1960s (Ang \& Nadarajan, 1996; Asiuzzaman, 2010). Consequently, social cohesion became an important government policy for nation-building and informed Singapore's future media legislation (Harish, 2013).

In comparison, Fiji had had a relatively smooth path to Independence and the push for greater media regulation was somewhat milder. However, some pressure continued to build during the heady 1980s and 1990s, when deregulation was the government motto. Government-media tensions peaked in 1999, when the Fiji Labour Party leader Mahendra Chaudhry became Fiji's first Prime Minister of Indo-Fijian descent. Unsettled by the relentless criticisms, Chaudhry went as far as to accuse then-News Limited-owned Fiji Times of 'subversive actions and provoking racism and sedition' (various researchers and analysts supported Chaudhry’s claims retrospectively, e.g., Gaunder, 2008; Robie, 2001). 
POLITICAL JOURNALISM IN THE ASIA-PACIFIC

Chaudhry threatened a 'swift justice' tribunal to curb a 'distorting, lying and seditious' press (Chaudhry, 2000, pp. 6-10). However, he was prematurely ousted by the 2000 coup. Some analysts blamed the coup on the Chaudhry government's alleged insensitivity towards indigenous fears and perceptions and questionable decision-making and nepotism. Such critics included two former Fiji Times editors-in-chief, Russell Hunter and Netani Rika. Both were forced to defend their positions as colonial-era claims about The Fiji Times' anti-Indo-Fijian agenda re-surfaced, along with claims about the Murdoch Media Empire's alleged anti-Labour agenda (see Hunter, 2009; Rika, 2009; Robie, 2001; T. R. Singh, 2011).

The 2000 coup was a watershed event for media freedom in Fiji. Spooked by the Chaudhry government's fall, future governments intensified censorship efforts. The Laisenia Qarase-led government, elected in 2001, tabled the Media Council of Fiji Bill, only to drop it in the face of a fierce 'No Media Bill' campaign mounted by the media sector (Government of the Republic, 2003). After winning a fresh mandate to govern in 2006, the Qarase government looked poised to re-introduce the media bill, but was ousted in the 2006 Bainimarama coup ('Don't blame media, 2006).

Soon after seizing power in December 2006, the military-backed Bainimarama government embarked on the most intense and sustained media crackdown in the country's history. Initially its agents intimidated and maltreated journalists, but later on adopted more sophisticated strategies, such as the use of decrees and emergency laws (see Dutt, 2010). A major piece of legislation, the Public Emergency Regulation (PER), was activated a day after the April 9, 2009 landmark ruling by the Fiji Court of Appeal declaring the 2006 coup unlawful.

The PER gave the government sweeping powers to censor news and revoke the licences of offending media outlets, enforced by official censors placed in all Fiji newsrooms (Public Emergency Regulation, 2009). The PER was continuously extended before it was lifted nearly three years later in January 2012, only to be replaced by the Public Order Act Amendment Decree (POAD), which allowed the use of force to maintain public order (Public Order (Amendment) Decree, 2012 United States Department of State, 2013, p. 9).

The core media legislation, the Media Industry Development Decree 2010, purports to incorporate all media-related laws. The decree stipulates stiff fines and jail terms for any breaches, with compliance overseen by the five-member Media Industry Development Authority (MIDA). The relevant minister appoints the chairperson and five other members, headed by the Solicitor-General (chairperson), or his/her nominee - an obvious conflict of interest (Media Industry Development Decree, 2010, p. 734). The minister may also direct the functions of the Authority, amend media codes as MIDA recommends, and issue policy and financial guidelines to the Tribunal (pp. 749-755).

The single-member Tribunal — a qualified judge — is appointed by the President, on the Attorney-General's advice, to adjudicate on reported media breaches. The Attorney-

132 PACIFIC JOURNALISM REVIEW 21(1) 2015 
General can be heard at Tribunal proceedings and/or table submissions in writing (Media Industry Development Decree, 2010, pp. 739-741).

The media code of practice, general code of practice for advertisements and the television programme classification are virtually the same as those of the now-defunct Fiji Media Council, except that what were once regarded as ethical breaches are now treated as criminal offences (Media Industry Development Decree, 2010).

Section 22 disallows any material that is against the 'public interest or order', against 'national interest', or 'creates communal discord', without adequately defining these terms (Media Industry Development Decree, 2010, pp. 738-739). MIDA can procure an order from the Tribunal to force the disclosure of confidential sources, except in cases of State corruption (Media Industry Development Decree, 2010).

Upon conviction, media organisations can be fined up to F $\$ 100,000(\$ N Z \$ 65,000)$; publishers or editors up to F $\$ 25,000$ ( $\$ N Z 16,240)$; and journalists up to F\$1000 (\$NZ650), and/or two years' imprisonment. The Tribunal can also order restitution of up to $\mathrm{F} \$ 100,000$ to complainants who win their cases. Culpable publishers and editors are liable to pay up to $\$ F 25,000$ and journalists up to $\$ F 1000$, enforceable through the High Court (pp. 751-762). These are hefty sums relative to salaries and the size of Fiji's media industry. In addition, MIDA and the Tribunal have virtual protection from legal liabilities (p. 755).

Some other significant legislation relating to the media includes:

- Television (Amendment) Decree 2012 (2012, p. 1439), which empowers the minister to 'revoke' or 'vary' the licence of any broadcaster deemed to have breached the media decree.

- State Proceedings (Amendment) Decree 2012 (2012), which shields all government ministers from defamation lawsuits. The same immunity is extended to media organisations that reported ministers' defamatory comments (Government nullified this decree in July 2014).

- Political Parties ... (Amendment) Decree (2013), which bars media from reporting on or representing political parties that had been deregistered from contesting the 2014 elections (Political parties, 2013, p. 145).

In September 2013, the Bainimarama government gazetted a new Constitution, with elections held in September 2014, bringing Bainimarama's Fiji First Party to power. The 2013 Constitution's Bill of Rights enshrines the right to 'freedom of speech, expression, thought, opinion' and 'freedom of the press', subject to national security threats, or prevention of hate speech and inaccurate, offensive media reports (Constitution of the Republic of Fiji, 2013, pp. 12-13). However, section 173(1-4), Preservation of laws, retains the interim government's decrees, including the 2010 Media Decree. The Media Decree, extraordinarily, prevails over the constitution in the event of any inconsistencies, even though this is subject to legal challenge (pp. 112-114).

Analysis of the first indicator of the efficacy of media law, the history of the legislation, suggests that despite constitutional guarantees, media freedom has always been 
POLITICAL JOURNALISM IN THE ASIA-PACIFIC

fragile in Fiji's 'hybrid' democracy, which is based on a combination of Western and Indigenous systems of governance (Boege et al., 2013).

The analysis suggests that indigenous cultural norms of respect for traditional authority and avoidance of open criticism (Madraiwiwi, 2014) were used to entrench elite indigenous power through provisions in the 1990 Constitution. Another variable was the racially-based electoral system. This meant that media had to cope with the general population's ethnic-based, partisan political affiliations (see Madraiwiwi, 2014; Sutherland, 1992). In other words, because of the nature of politics in Fiji, there is a high risk of the media antagonising all sides of the political and ethnic divides and ending up friendless. For instance, opinion polls in 2011 indicated a measure of public support for tighter media controls (Lowy Institute, 2011). Indeed, the Qarase government won 2006 election despite earlier tabling an anti-media bill. Later, the Bainimarama government won the 2014 election despite, or perhaps because of, promulgating the punitive 2010 media decree.

These developments suggest that in Fiji's political and cultural contexts, an overlyaggressive watchdog approach could be self-threatening. It could turn the public against the Fourth Estate, which in turn could strengthen government's case for tighter regulation. It seems Fiji's media not only face autocratic-minded governments, but also at times a cagey, untrusting and coup-weary public. This resembles, in the Fiji context, what Dalton and others (1998) describe as 'hostile media phenomenon'. The term derives from a 1992 study of the US presidential election, which identified a strong tendency among partisan Republican and Democrat supporters to regard even balanced news coverage of their political side as biased (see Dalton, Beck \& Huckfeldt, 1998).

The analysis now moves to the second indicator of the three.

Degree of media freedom established in the country's media laws

In terms of the second indicator, 'degree of media freedom established in the country's laws', analysis of the Media Decree indicates that government controls the important functions of MIDA and the Tribunal through three key officials - the President, the minister concerned, and the Attorney-General. These officials make the appointments and as such, exercise certain control and influence over the media authority, which raises questions about the separation of powers relating to 'executive, legislative and judicial' functions (see International Senior Lawyers Project, 2013. p. 2).

Another issue is the sweeping nature of some provisions, such as section 22, which bars any content that is 'against public interest or order; against the national interest; or creates communal discord', without adequately defining these terms (Media Industry Development Decree, 2010, p. 739). The Tribunal's power to order media to pay compensation to complainants increases the risk of frivolous actions. This threat did not materialise in the first four years of the decree, but there is nothing to stop someone from setting a precedent. This provision is questionable when the country's defamation laws are still intact.

134 PACIFIC JOURNALISM REVIEW 21(1) 2015 
With regard to the minister's emergency powers (Media Industry Development Decree, 2010; pp. 749-755), the International Senior Lawyers Project (2013) concedes that even in democratic societies, certain narrowly-defined State interests, such as the prevention of imminent violence, could justify some restrictions. However, the precedence in Fiji shows that emergency rule could be open to misuse. The PER, promulgated in April 2009, was continuously renewed before being lifted almost three years later (see Lauder, 2012).

As mentioned earlier, social stability was cited as a major justification for stronger legislation. However, in the internet age, it is virtually impossible to exercise full control over the media. The Government crackdown possibly drove dissenting views into the blogosphere, where they re-emerged in more virulent forms (see Hammond-Thrasher, 2007; Walsh, 2010). At its peak, around 72 blogs were reportedly expressing opposition to the Bainimarama government: a 'heady mix of rumours, misinformation, incitement to racial violence, calls for revolution, hate crime and even terrorism' (Hammond-Thrasher, 2007; also see C. Walsh, 2010).

These findings defy Bainimarama's (2012) claims that tougher legislation would deter 'self-interested individuals' who 'fan the flames of prejudice and intolerance'. It lends credence to Hackett's assertion that the 'solution of censorship' can be 'worse than the cure' (2013, p. 36). The Fiji situation indicates that an enabling national regulatory framework for journalism may be better founded on a certain level of openness. As media commentator Simon O'Connor states, media's first role in nation-building is to critique the style of the nation being created. To reverse this situation can lead to facts and serious questions being left out to facilitate only one group's vision of the nation (Fiji Media Watch, 2003).

O'Connor's perspective also relates to the Media Decree's disclosure provisions. Cases concerning state corruption are exempt, but MIDA can, under warrant, search premises and confiscate material (Media Industry Development Decree, 2010). In such swoops, the identity of confidential sources could be at risk, discouraging whistleblowing in a region where journalists often rely on 'judicious leaks' (Larmour, 2006). This indicates how the 2010 Media Decree could work against the very objectives Bainimarama staked his coup on, such as anti-corruption (Bainimarama, 2010, 2012).

In sum, the second indicator, 'degree of media freedom established in the country's laws', shows an imbalance favouring state power. The analysis moves to the third and final indicator.

Consistency and fairness in the application of the legislation

Regarding the final indicator, 'consistency and fairness in the application of the legislation', further insights can be gained through the interpretation of an independent review of the Fiji Media Council in 2009. The report, Free and Responsible: Towards a more effective Fiji Media Council, argued that statutory regulation would undermine press 
freedom by replicating the legal system's 'delays, costs and complexities' (Herman et al., 2009, pp. 5-40). This warning is valid. There are apparent duplications between section eight of the Media Decree, which prohibits the publication of material likely to 'create communal discord' (p. 739) and the comprehensive Public Order Act, which covers racial and religious vilification and hate speech (Crimes Decree, 2009).

The media decree notwithstanding, Fiji's defamation laws are still intact. Furthermore, the government has been vigorously enforcing any media breaches under pre-existing contempt of court legislation, with two successive prosecutions against The Fiji Times in 2011 and 2013 (Tough week and times, 2013). Still on defamation, the State Proceedings (Amendment) Decree 2012 (2012), shielding all government ministers from defamation lawsuits, is another example of inconsistent, lopsided legislation, even though the government nullified this decree in July 2014.

Another possible case of over-regulation is the provision requiring all news stories to be 'balanced' (Media Industry Development Decree, 2010). This requirement has allegedly become a loophole for parties wanting to thwart media scrutiny. Such parties simply would not respond to media questions, making it impossible to fulfill the requirement for balance. It is alleged that if a story was positive towards the Government, the requirement for balance was ignored (see United States Department of State, 2013). If true, this is an example of how the state can selectively apply such laws in its favour.

Government has continued to pass laws to strengthen its hold over the media. The Television (Amendment) Decree 2012 not only empowers the minister to 'revoke' or 'vary' the licence of any broadcaster deemed to be in breach of the decree, it also stops aggrieved parties from challenging the decision through the courts (Television (Amendment) Decree, 2012). This decree was apparently used against Fiji Television following the expiry of its 12-year broadcasting licence in May 2012, with Attorney-General Sayed-Khaiyum opting to approve six-month temporary renewals only instead of a full renewal (No word on renewal, 2012).

The apparent inconsistencies in the legislation notwithstanding, whether future governments institute change is open to question. Normally, the trend is not to surrender hard-won power over the media. Singapore, which served as a model for Fiji's 2010 Media Decree, first imposed stricter laws in the name of social stability and economic development. Over the decades, even as Singapore became an international economic powerhouse, government used various tactics to tighten its hold on the media. The more sophisticated and subtler controls included harnessing market forces to apply pressure on the media (George, 2012).

On the other hand, analysts such as Robie (2009) believe that in Fiji, an element of 'hypocrisy' exists about media freedom, with little industry acknowledgment that the country's media do have shortcomings. Robie points out that the controversial Anthony Report echoed media weaknesses identified by the Thomson Foundation review more than a decade earlier (2009, pp. 109-111).

136 PACIFIC JOURNALISM REVIEW 21(1) 2015 
In terms of the third and final indicator, 'consistency and fairness in the application of the legislation', the research indicates that some laws are duplicitous, selectively applied and advantage the Government. On the media's part, the literature denotes weaknesses in terms of ethics and professionalism, as outlined in several reports (Herman et al., 2009; also see Robie, 2009).

\section{Conclusion}

While Fiji's constitutions enshrined freedom of speech, the spectre of tighter legislation has been a constant threat due to cultural, political and social factors. Post-2006 coup, Fiji suffers from over-regulation, with too much power in Government hands, and insufficient space and protection for the media to carry out their monitorial role to the fullest extent. In certain areas of law, there is evidence of duplication, with media organisations and journalists answerable both to the court system and to the Media Tribunal for similar offences. While the legislative reforms were instituted in the name of social stability, the restrictions may have caused opposition views to migrate to social media sites, where they resurfaced in more extreme forms.

The application of the legislation is somewhat inconsistent. Moreover, the post-2006 coup Government continued to pass media laws, which were later used to its advantage.

However, there seems to be some public support for the Bainimarama government's media policy, evident in the 2009 Lowy Poll and in Bainimarama's win in the 2014 General Election. If the 2014 election results are anything to go by, the majority of voters placed greater value on the Bainimarama government's promises of development and progress than on media freedom. The intriguing question is whether Fiji voters assume a negative co-relation between media freedom and development. Empirically speaking, the link between the two with regards to Fiji is fuzzy at best, and needs further research.

This research highlights the need for greater consultation between government and the media industry on the complex but crucial issue of future media legislation in Fiji. Any such negotiations will likely be fraught with difficulties, not the least because of differences in opinion between the state and the media sector about the 'proper' role and function of the national media. As a start, the media sector needs to acknowledge its weaknesses and show willingness to take corrective action. Government, on its part, needs to address the various grievances concerning the Media Decree.

\section{References}

Ang, P. H., \& Nadarajan, B. (1996). Censorship and the internet: a Singapore perspective. Communications of the ACM, 39(6), 72-78.

Bainimarama has final say. (2010, September 10). Fiji Sun. Retrieved on December 27, 2013, from www.fijisun.com.fj/2010/09/10/bainimarama-has-the-final-say/

Bainimarama, V. (2012, January 1). Address on the removal of Public Emergency Regulations by Fijian PM Commodore Bainimarama. Retrieved on July 18, 2013, from www.foreignaffairs. 


\section{POLITICAL JOURNALISM IN THE ASIA-PACIFIC}

gov.fj/media-resources/media-release/186-address-on-the-removal-of-public-emergency-regulations-by-fijian-pm-commodore-bainimarama

Boege, V., Casimira, A., Ernst, M., \& Szesnat, F. (2013). Voices of the people: perceptions and preconditions for democratic development in Fiji. Suva: Institute for Research and Social Analysis, Pacific Theological College.

Christians, C., Glasser, T., McQuail, D., Nordenstreng, K., \& White, R. (2009). Normative theories of the media: journalism in democratic societies. Urbana, IL: Illinois University Press.

Constitution of the Republic of the Fiji Islands 1997. (1997). Retrieved on November 19, 2013, from www.constitutionnet.org/files/1997_constitution.pdf

Constitution of the Republic of the Fiji Islands 2013. (2013). Retrieved on November 19, 2013, from www.fiji.gov.fj/getattachment/8e981 ca2-1757-4e27-88e0-f87e3b3b844e/Click-here-todownload-the-Fiji-Constitution.aspx

Constitution of the Sovereign Democratic Republic of Fiji 1990. (1990). Retrieved on November 19, 2013, from www.constitutionnet.org/files/1990_constitution.pdf

Crimes Decree 2009. (2009). Government Gazette. (Vol. 10, N. 95).

Dalton, J., Beck, P., \& Huckfeldt, R. (1998). Partisan cues and the media: Information flows in the 1992 presidential election. American Political Science Review, 92(1), 111-126.

Digitaki, T. (2000, April). Reading between the lines. Pacific Media Watch Fiji 2673. Retrieved on April 28, 2012, from www.asiapac.org.fj/cafepacific/resources/aspac/fiji2673.html

'Don't blame media,' says journalism academic. (2006, September 6). Pacific Media Watch Fiji 5006. Retrieved on August 14, 2013, from http://kauri.aut.ac.nz:8080/dspace/ handle/123456789/1173

Dutt, R. (2010). The Fiji media decree: A push towards collaborative journalism.

Pacific Journalism Review, 16(2), pp. 81-98.

Ewins, R. (1998). Colour, class and custom: the literature of the 1987 Fiji coup. Retrieved on December 12, 2011, from http://speedysnail.com/pacific/fiji_coup/

Fiji Independence Order 1970 and Constitution of Fiji. (1970). Retrieved on November 19, 2013, from www.constitutionnet.org/files/1970_constitution.pdf

Fengler, S., \& Ruß-Mohl, S. (2008). Journalists and the information attention markets: Towards an economic theory of journalism. Journalism, 9(6), 667-690.

Fiji Human Rights Commission. (2008). Freedom and independence of the media in Fiji: A report [James Anthony report]. Retrieved on March 22, 2009, from http://kauri.aut.ac.nz:8080/dspace/ bitstream/123456789/79/1/fhrcmediarpt2007. Pdf

Fiji Media Watch. (2003). Media awareness [Newsletter]. Suva, Fiji Media Watch.

Firth, S. (2000). The Pacific Islands and the globalisation agenda. Contemporary Pacific, 12(1), $177-192$.

Fong, N. (2009). Framing the analysis of a conflict: war/peace journalism. The Journal of the South East Asia Research Centre for Communications and Humanities, 1(1), 17-32.

Frohardt M., \& Temin, J. (2003). Special report: use and abuse of media in vulnerable societies. Washington, DC: United States Institute for Peace.

Gaunder, P. (2008). The media and the truth. Fijian Studies, 9(6), pp. 250-270.

George, C. (2012). Freedom from the press: journalism and state power in Singapore. Singapore: NUS Press.

Gillion, K. (1977). The Fiji Indians: A challenge to European dominance 1920-1946. Australian National University, Canberra.

Government of the Republic of the Fiji Islands. (2003). Fiji Media Council of Fiji Bill 2003: Suva, Fiji: Government of the Republic of the Fiji Islands.

138 PACIFIC JOURNALISM REVIEW 21(1) 2015 
Grynberg, R., L., Munro, D., \& White, M. (2002). Crisis: the collapse of the National Bank of Fiji. Suva, Fiji: University of the South Pacific Book Centre.

Hackett, R. (2013). Press freedom and communication rights: What kind of journalism does democracy need? Pacific Journalism Review, 19(1), 13-40.

Hammond-Thrasher, C. (2007). Blogs, the laws of the USA, and why Fiji is really crying. Retrieved on August 28, 2012, from http://dfiji.blogspot.com.au/search?q=heady+mix+uttering+

Harish, S. (2013, August 23). Do policy prescriptions work? Studying effect of race and religion on people's behaviour. Eurasia Review. Retrieved on August 26, 2013, from www. eurasiareview.com/23082013-do-policy-prescriptions-work-studying-effect-of-race- and-religion-onpeoples-behaviour-analysis/

Herman, J., Siwatibau, S., \& Sweetman, B. (2009). Free and responsible: Towards a more effective Fiji Media Council. Report of the 2009 review. Suva: Fiji Media Council.

Houge, R. (2011). Constructivism and qualitative research. Retrieved on January 19, 2015, from http://rjh.goingeast.ca/2011/10/15/constructivism-and-qualitative-research/

Hunter, R. (2009). State control and self-censorship in the media after the coup. In J. Fraenkel., S. Firth \& B. V. Lal (Eds.), The 2006 military takeover in Fiji: a coup to end all coups? (pp. 277-290). Canberra, ACT: ANU Press.

International Senior Lawyers Project. (2013). Fiji Media Industry Development Decree 2010 issues list and best practices summary. Retrieved on March 9, 2014, from www.islp.org/sites/default/ files/Fiji\%20Media\%20Decree\%20Issues\%20List\%20\%2817\%20Jan\%202013\%29_0.pdf

Kant, S. (2012, December 1). Temporary folly. [Web log message]. Retrieved on December 2, 2012, from http://crosbiew.blogspot.com.au/2012/12/temporary-folly.html

Larmour, P. (2006, March 30). Culture and corruption in the Pacific Islands: Some conceptual issues and findings from studies of National Integrity Systems. (Policy and Governance Discussion Paper 06-05). Canberra, Australia: Asia-Pacific School of Economics and Government, The Australian National University.

Lauder, S. (2012, January 7). Fiji lifts emergency laws but imposes public order decrees. $A B C$ News. Retrieved on May 11, 2012, from www.abc.net.au/am/content/2012/s3403560.htm

Lowy Institute for International Policy. (2011). Fiji at home and in the world: Public opinion and foreign policy. NSW, Australia: Lowly Institute for International Policy.

Madraiwiwi, J. (2014, March 18). Beyond a culture of silence. Repúblika. Retrieved on June 12, 2014, from http://republikamagazine.com/2014/03/beyond-a-culture-of-silence/

McLeod, A. (2009). Paradigms in research; or, how your worldview shapes your methodology. Retrieved on January 19, 2015, from https://mackle.wordpress.com/2009/04/21/ paradigms-in-research-or-how-your-worldview-shapes-your-methodology/

Media Industry Development Decree 2010. (2010). Republic of Fiji Islands Government (Decree No. 29 of 2010).

Morgan, K., \& Thomas, J. P. (1996). Future media legislation and regulation for the republic of the Fiji Islands. [Consultancy report.] Cardiff: The Thomson Foundation.

Naidu, V. (2013). Fiji: the challenges and opportunities of diversity. Retrieved on August 9, 2013, from www.minorityrights.org/?lid $=11850$

No word on renewal of Fiji TV licence. (2012, June 29). Radio New Zealand International. Retrieved on March 16, 2013, from www.radionz.co.nz/international/pacific-317 news/205571/ no-word-on-renewal-of-fiji-tv-licence

Pareti, S. (2009). The Fiji coup six months on: The role of the media. In J. Fraenkel., S. Firth \& B. V. Lal (Eds.), The 2006 military takeover in Fiji: A coup to end all coups? (pp. 70-114). Canberra, ACT: ANU Press. 


\section{POLITICAL JOURNALISM IN THE ASIA-PACIFIC}

Pearson, M. (2007). The journalist's guide to media law: Dealing with legal and ethical issues (3rd ed.). Crows Nest, NSW: Allen \& Unwin.

Political Parties (Registration, Conduct, Funding and Disclosures) Decree 2013. (2013). (Decree No. 4 of 2013). Republic of Fiji Islands Government.

Press Council to offer membership to blogs. (2014, March 23). The New Zealand Herald. Retrieved on March 29, 2014, from www.nzherald.co.nz/nz/news/article.cfm?c id=1\&objectid=11224880

Public Emergency Regulation 2009. (2009). Republic of Fiji Islands Government Gazette. (Vol. 10, No. 5).

Public Order (Amendment) Decree 2012. (2012). Republic of Fiji Islands Government Gazette (Vol 13, No. 1).

Rabuka and the reporter. (1994). Pacific Journalism Review, 1(1), pp. 20-22.

Reddy, S. (2010, June). The future for Fiji's economy. Speech presented at the Fiji Institute of Accountants, Yanuca, Fiji.

Rika, N. (2009). Untitled speech presented at the Pacific Islands News Association convention, Port Vila. Retrieved on May 10, 2013, from www.mediafire.com/?yjxdvnmlylw

Robie, D. (2014). Don't spoil my beautiful face: Media, mayhem and human rights in the Pacific. Auckland: Little Island Press.

Robie, D. (2013). The 'talanoa' and the tribal paradigm: reflections on cross-cultural reporting in the Pacific. Australian Journalism Review, 35(1), 43-58.

Robie, D. (2009). Behind the Fiji censorship: A comparative media regulatory case study as a prelude to the Easter putsch. Pacific Journalism Review, 15(2), 85-116.

Robie, D. (2001). Coup coup land: the press and the putsch in Fiji. Asia Pacific Media Educator, $10,148-62$.

Sayed-Khaiyum, A. (2010). Commencement of the Media Industry Development Decree 2010. Retrieved on July 18, 2013, from http://pacific.scoop.co.nz/2009/10/think-outside-box-tocover-real-stories-about-social-change-says-sayed-khaiyum/

Singh, S. (2010). Life under Decree No. 29 of 2010: The Fiji Media Development Decree. Pacific Journalism Review, 16(2), 147-162.

Singh, S. (2012). Investigative journalism: Challenges, perils, rewards in seven Pacific Island countries. Pacific Journalism Review, 18(1), 83-104.

Singh, T. R. (2011). The 2000 Speight coup in Fiji: An analysis of the role of The Fiji Times and the impact of partisan media. (Unpublished Masters in Communication Studies thesis, School of Communication Studies, Auckland University of Technology, 2011). Retrieved on April, 2012, from http://aut.researchgateway.ac.nz/handle/10292/2554

State Proceedings (Amendment) Decree 2012. (2012). Republic of Fiji Islands Government Gazette. (Vol. 13, No. 19).

Sutherland, W. (1992). Beyond the politics of race: An alternative history of Fiji to 1992. Canberra: Australian National University.

Television (Amendment) Decree 2012. (2012). Republic of Fiji Government Gazette. (Vol. 13, No. 88). Tough week and times ahead for Fiji media. (2013, February 20). Pacific Freedom Forum. Retrieved on April 29, 2013, from www.pacificfreedomforum.org/2013/02/tough-week-andtimes-ahead-for-fiji.html

United States Department of State. (2013, April 19). 2012 Country Reports on Human Rights Practices - Fiji. Retrieved on August 20, 2013, from www.refworld.org/ docid/517e6e3818.html

Usman, S. (2012). Invisibility in the media: a comparative analysis of the coverage given to female election candidates in the 1999 and 2006 elections by The Fiji Times and Fiji Sun (Unpublished doctoral thesis, University of the South Pacific, 2012).

140 PACIFIC JOURNALISM REVIEW 21(1) 2015 
Walsh, C. (2010). Political blogs on Fiji: A ‘cybernet democracy' case study. Pacific Journalism Review, 16(1), 154-177.

Shailendra Singh is head of journalism in the School of Literature and Media (SLAM) at the University of the South Pacific, Fiji, and a doctoral candidate at the University of Queensland. $\mathrm{He}$ is also a former editor of The Review news and current affairs magazine in Fiji and is currently a correspondent for the Inter Press Service. An earlier version of this article was originally presented at the PJR2014 'Political Journalism in the Asia-Pacific' conference at Auckland University of Technology in New Zealand on 27-29 November 2014.

shailendra.singh@uqconnect.edu.au

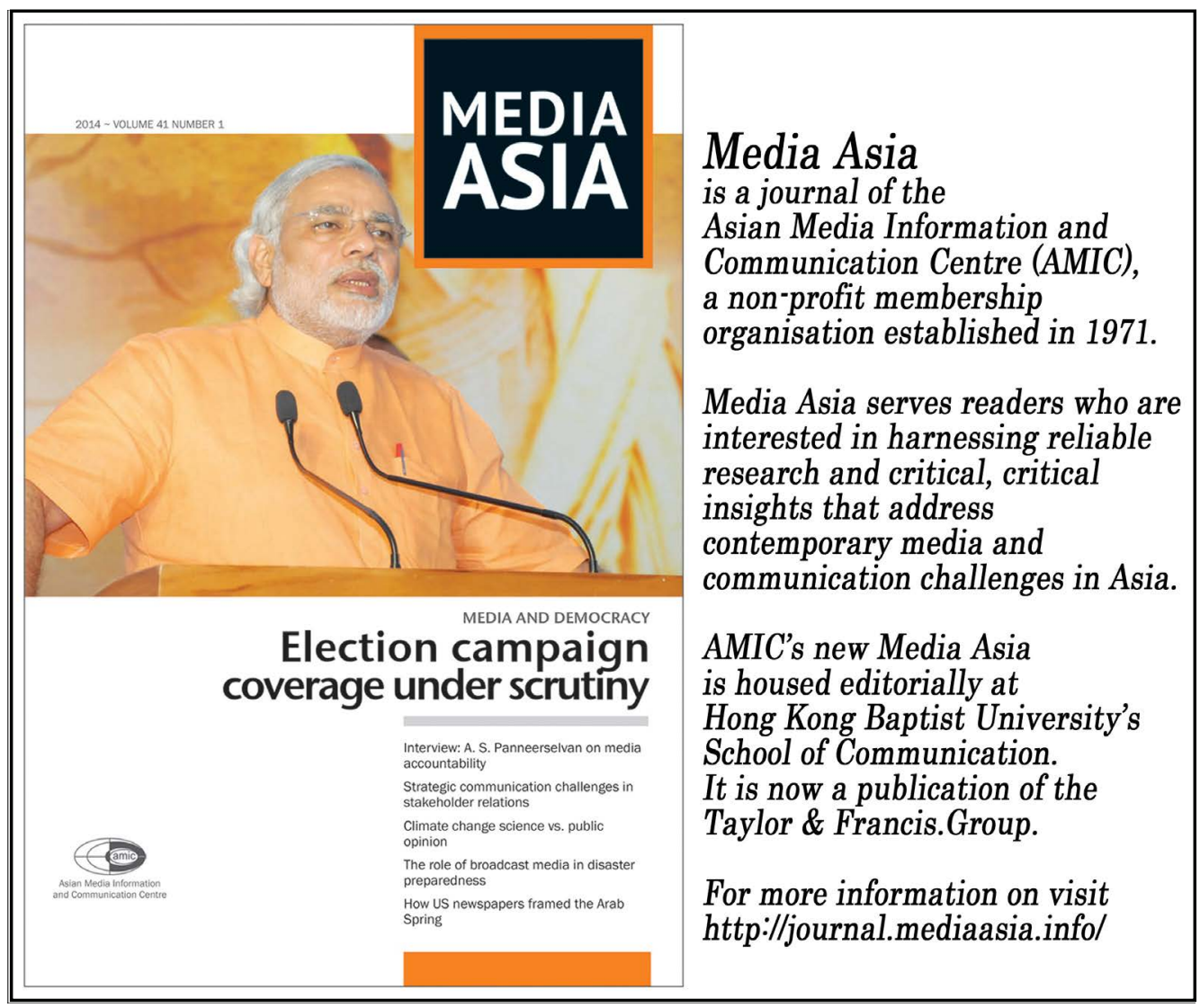

PACIFIC JOURNALISM REVIEW 21 (1) 2015141 